\title{
APLIKASI SISTEM INFORMASI GEOGRAFIS (SIG) UNTUK ANALISIS AKSES TERDEKAT DAN JUMLAH PERGERAKAN PENDUDUK MELEWATI JALUR EVAKUASI DI KOTA PADANG
}

\author{
Afrital Rezki \\ Program Studi Pendidikan Geografi STKIP PGRI Sumatera Barat \\ afrital.rezki@gmail.com
}

\begin{abstract}
Research on the location and evacuation pathways important as an effort to mitigate the earthquake and tsunami. The geological, geomorphological and climatological, several areas in the city of Padang is indicated as a disaster-prone areas that need to be done a variety of disaster mitigation efforts. The purpose of this study was to analyze (1) the evacuation route and the service sector that any evacuation routes, and (2) an analysis of the movement of residents in the evacuation path. The method used is the analysis of GIS with spatial-based descriptive research method to describe the area of research with qualitative data and this kuantitatif. Saat in Padang there are 10 evacuation route sectors which are directly related to the safe zone. The road is used as an evacuation route and have a sufficient width is Jln. Adinegoro with a width of $16 \mathrm{~m}$. Which is the main road evacuation but did not have sufficient width is Jln. Black stumps with a width of only 3 $m$. The amount of movement of the population most at-prone zones leading to safe zones exist in the sector towards sector 7 as many as 51175 lives in the district. East Padang.

Keywords: SIG, Line Evacuation, population movements, Kota Padang
\end{abstract}

Abstrak

Penelitian tentang lokasi dan jalur evakuasi penting dilakukan sebagai salah satu upaya mitigasi bencana gempa dan tsunami. Secara geologis, geomorfologis, dan klimatologis, beberapa kawasan di Kota Padang diindikasikan sebagai kawasan rawan bencana sehingga perlu dilakukan berbagai upaya mitigasi bencana. Tujuan dari penelitian ini adalah untuk menganalisis (1) jalur evakuasi dan sektor yang menjadi pelayanan setiap jalur evakuasi, dan (2) analisis pergerakan penduduk di jalur evakuasi. Metode yang dilakukan adalah analisis SIG dengan metode penelitian deskriptif berbasis keruangan untuk menggambarkan wilayah penelitian dengan data-data kualitatif dan kuantitatif.Saat ini di Kota Padang terdapat 10 sektor jalur evakuasi yang berhubungan langsung dengan zona aman. Jalan yang dijadikan jalur evakuasi dan memiliki lebar yang cukup adalah Jln. Adinegoro dengan lebar 16 m. Jalan yang menjadi jalur evakuasi tetapi tidak memiliki lebar yang cukup adalah Jln. Tunggul Hitam dengan lebar hanya $3 \mathrm{~m}$. Jumlah pergerakan penduduk paling banyak di zona rawan yang menuju zona aman ada pada sektor yang menuju sektor 7 sebanyak 51.175 jiwa di Kec. Padang Timur.

\section{PENDAHULUAN}

Indonesia merupakan negara yang rawan terhadap bencana alam karena terletak pada daerah yang aktif tektonik dan vulkanik sebagai akibat pertemuan tiga lempeng tektonik, yaitu Lempeng India-Australia, Pasifik, dan Eurasia. Salah satu bencana alam yang sering terjadi di Indonesia adalah bencana banjir(Sutikno, 1995).Bencana alam merupakan peristiwa alam yang diakibatkan oleh proses alam, 
baik yang terjadi oleh alam itu sendiri maupun diawali oleh tindakan manusia, yang menimbulkan risiko dan bahaya.

terhadap kehidupan manusia baik harta benda maupun jiwa. Karakteristik bencana alam ditentukan oleh karakteristik lingkungan fisik seperti; iklim, topografi, geologi, tanah, tata air, penggunaan lahan dan aktivitas manusia. Secara geologis, geomorfologis, dan klimatologis, beberapa kawasan di Kota Padang diindikasikan sebagai kawasan rawan bencana sehingga perlu dilakukan berbagai upaya mitigasi bencana.

Mempersiapkan jalur dan lokasi evakuasi merupakan salah satu hal yang paling penting dalam mitigasi bencana. Evakuasi terdiri dari evakuasi vertikal dan evakuasi horizontal. Menurut Trisler (2004), evakuasi vertikal adalah memindahkan atau mengarahkan penduduk atau orang-orang ke lantai atas bangunan yang memadai konstruksinya, sedangkan evakuasi horisontal adalah memindahkan atau mengarahkan penduduk atau orang-orang ke lokasi-lokasi yang lebih jauh atau pada lahan yang tinggi.

Geographic Information System (GIS) dibangun untuk meningkatkan kreativitas dan inovasi juga memacu pengembangan perangkat lunak melalui pengembangan Sistem Informasi Geografis berbasis web, sehingga dapat membantu program pemerintah terutama untuk penanganan bencana. Sistem Informasi Geografis itu sendiri diartikan sebagai sistem informasi yang digunakan untuk memasukkan, menyimpan, memangggil kembali, mengolah, menganalisis dan menghasilkan data bereferensi geografis atau data geospatial, untuk mendukung pengambilan keputusan dalam perencanaan dan pengelolaan penggunaan lahan, sumber daya alam, lingkungan transportasi, fasilitas kota, dan pelayanan umum lainnya (Prahasta, 2001).

Menurut UU No. 24 Tahun 2007 mengenai mitigasi bencana, salah satu kesiapsiagaan dalam menghadapi bencana adalah penyiapan lokasi evakuasi. Kota Padang sebagai salah satu Kota yang sangat rawan terhadap bencana tsunami, perlu mempersiapkan jalur dan lokasi evakuasi yang dapat menampung semua korban. Saat ini Kota Padang telah merencanakan jalur dan lokasi evakuasi sebagai upaya 
mitigasi bencana tsunami akan tetapi belum ada yang dapat menjamin lokasi evakuasi tersebut telah siap untuk digunakan.

Setiap kecamatan dan kelurahan di Kota Padang yang merupakan daerah rawan Tsunami seharusnya dilengkapi dengan adanya peta jalur evakuasi dan lokasi evakuasi, penting sekali disediakan secukupnya peta jalur evakuasi di Kota Padang. Secara umum masalah penelitian adalah bagaimanakah jalur evakuasi dan sektor yang menjadi pelayanan setiap jalur evakuasi di Kota Padang, dan bagaimanakah pergerakan penduduk melewati jalur evakuasi di Kota Padang.

\section{METODOLOGI}

Penelitian ini dilakukan dengan metode penelitian deskriptif, yaitu penelitian yang menggambarkan daerah penelitian dengan data-data kualitatif dan kuantitatif serta gambar-gambar lapangan. Data kualitatif merupakan data yang diperoleh langsung di lapangan, sedangkan data kuantitatif merupakan data yang telah diolah untuk melihat tingkat bahaya dan risiko bencana yang terjadi atau berpotensi terjadi di Kota Padang.

1. Metode pengumpulan data

Kegiatan pengumpulan data dilakukan dengan 2 pendekatan yaitu pendekatan dengan metoda survey lapangan dan pendekatan dengan metoda survey instansional. Pendekatan pertama, yaitu survey lapangan untuk mendapatkan data primer yang dilaksanakan dengan cara :

a. Pengamatan langsung terhadap objek data.

b. Pengambilan foto untuk memperoleh gambaran visual

Pendekatan kedua, yaitu survey instansional guna mendapatkan data-data sekunder yang dilaksanakan dengan cara Inventarisasi data spasial (peta) dan data kuantitatif dari beberapa instansi terkait, baik tingkat kelurahan, kecamatan dan pada lingkungan Pemko Padang. Studi literatur dari beberapa nara sumber yang dapat dipercaya kebenarannya.

2. Alat dan bahan

Alat yang digunakan dalam studi ini berupa GPS, softwere Arcview 3.2, kamera, komputer dan printer. Sedangkan bahan yang digunakan adalah peta topografi lembar padang skala 1: 50.000 tahun 1985 dan citra quick bird tahun 2006 
Data primer yang diamati dilapangan berupa: (1) kepadatan penduduk per sektor, (2) kondisi jalur evakuasi, (3) foto jalur evakuasi. Data sekunder yang dibutuhkan dalan studi ini berupa: (1) data kependudukan, (2) data statistik daerah studi, (3) Data RTRW, (5) data sebaran, dimensi, kualitas dan kuantitas dari infrastruktur.

3. Tahap pengolahan data

Dari hasil pengamatan dan pengambilan data di lapangan menghsilkan data primer yang menjadi data dasar dalam studi ini. Data tersebut di analisa untuk menentukan jalur evakuasi terdekat dan jumlah pergerakan penduduk pada tiap sektor di Kota Padang. Data-data yang telah terkumpul kemudian diolah menjadi data SIG dijital. Untuk mengubah data menjadi data SIG dapat dilakukan dengan dijitasi point, line dan poly. Hasil dari pengolahan data dalam SIG ini adalah peta dijital yang sudah dilakukan proses editing dan transformasi.

4. Tahap analisis data

a. Analisa untuk jalur evakuasi adalah semua jalan yang berhubungan langsung dengan zona aman disebut dengan jalur evakuasi utama, jalan yang menghubungkan komplek pemukiman dengan jalur evakuasi utama. Penentuan jalur evakuasi dikerjakan dengan analisa SIG.

b. Analisa untuk pergerakan penduduk dan jumlah pergerakan penduduk melewati jalur evakuasi ini dilakukan metode buffer dengan SIG sehingga didapatkan sektor-sektor yang dilayani oleh jalur evakuasi terdekat dengan pemukiman penduduk. Metode buffer ini dilakukan pada setiap kavling permukiman dengan buffer distance $200 \mathrm{~m}$. Dipilihnya buffer distance sepanjang 200 m dilakukan karena jarak antara dua jalur evakuasi terdekat yang ada di Kota Padang adalah 200 meter. Hasil dari buffer distance akan membentuk sektor-sektor pemukiman yang dekat dengan jalur evakuasi utama.

\section{PEMBAHASAN}

\section{A. Letak, Luas dan Penduduk}

Padang merupakan Ibukota Provinsi Sumatera Barat, yang terletak di pesisir pantai bagian Barat Sumatera Barat, dengan luas keseluruhan Kota Padang 
adalah 694,96 $\mathrm{km}^{2}$, terletak pada Bujur Timur $100^{0} 05^{\prime} 05^{\prime},-100^{0} 34^{\prime}$ 09', Lintang Selatan $00^{0} 44^{\prime} 00^{\prime \prime}-01^{0} 08^{\prime} 35^{\prime}$ '.

Batas- batas wilayah Kota Padang adalah sebagai berikut:

Bagian Utara : berbatasan dengan Kabupaten Padang Pariaman,

Bagian Timur : berbatasan dengan Kabupaten Solok,

Bagian Selatan : berbatasan dengan Kabupaten Pesisir Selatan,

Bagian Barat : :berbatasan dengan Samudera Hindia.

Kota Padang seperti terlihat pada peta berikut:

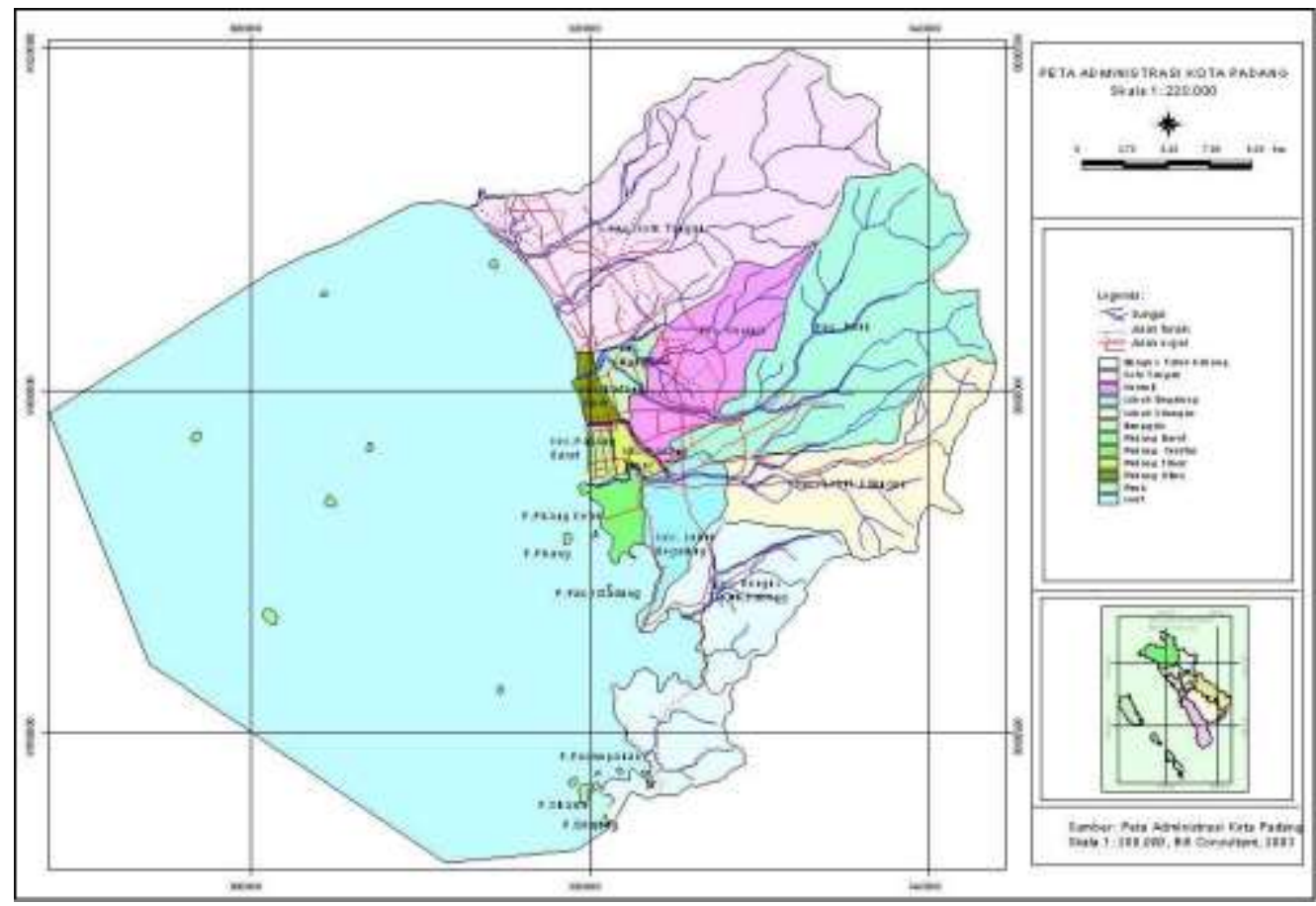

Tabel 3.1 Luas Kecamatan Jumlah Penduduk Dan Kepadaan Penduduk

Kota Padang

\begin{tabular}{|c|l|c|c|c|}
\hline NO & Kecamatan & $\begin{array}{l}\text { Luas } \\
\mathbf{( k m}^{\mathbf{2}}\end{array}$ & $\begin{array}{l}\text { Jumlah } \\
\text { Penduduk }\end{array}$ & $\begin{array}{l}\text { Kepadatan } \\
\mathbf{J i w a}_{\mathbf{k m}} \mathbf{2}\end{array}$ \\
\hline 1 & Kec. Bungus teluk kabung & 83 & 23.197 & 279 \\
\hline 2 & Kec. Koto tangah & 230 & 14.8264 & 645 \\
\hline 3 & Kec. Kuranji & 54 & 110.316 & 2.043 \\
\hline 4 & Kec. Lubuk begalung & 31 & 97.560 & 3.147 \\
\hline 5 & Kec. Lubuk kilangan & 84 & 40.538 & 483 \\
\hline 6 & Kec. Nanggalo & 9 & 55.669 & 6.185 \\
\hline
\end{tabular}




\begin{tabular}{|c|l|c|c|c|}
\hline NO & Kecamatan & $\begin{array}{l}\text { Luas } \\
\left.\mathbf{( k m}^{\mathbf{2}}\right)\end{array}$ & $\begin{array}{l}\text { Jumlah } \\
\text { Penduduk }\end{array}$ & $\begin{array}{l}\text { Kepadatan } \\
\text { Jiwa/km }\end{array}$ \\
\hline 7 & Kec. Padang barat & 5 & 59.657 & 11.931 \\
\hline 8 & Kec. Padang selatan & 13 & 60.022 & 4.617 \\
\hline 9 & Kec. Padang timur & 9 & 83.151 & 9.239 \\
\hline 10 & Kec. Padang utara & 8 & 72.766 & 9.096 \\
\hline 11 & Kec. Pauh & 165 & 50.204 & 304 \\
\hline & Jumlah & 691 & 801.344 & \\
\hline
\end{tabular}

Sumber analisis SIG 2014 dan data Sekunder.

Berdasarkan tabel diatas dapat dilihat kecamatan yang paling luas adalah Kecamatan Koto tangah dengan luas 230 ha dan kecamatan yang paling kecil adalah Kecamatan Padang Barat 5 ha. Kecamatan yang memiliki kepadatan penduduk paling tinggi adalah Kecamatan Padang Barat dengan kepadatan 11.931 jiwa/km, sedangkan Kecamatan yang memiliki kepadatan penduduk paling sedikit adalah Kecamatan Pauh dengan kepadatan 304 jiwa/km.

\section{B. Kelerengan}

Tabel 3.2 Klasifikasi Kemiringan Lereng, Luas Wilayah Dan Persentase Kota Padang

\begin{tabular}{|c|c|l|c|c|}
\hline $\begin{array}{c}\mathbf{N} \\
\mathbf{O}\end{array}$ & $\begin{array}{c}\text { Klasifikasi } \\
\text { Kemiringan }\end{array}$ & Lereng & $\begin{array}{c}\text { Luas Wilayah } \\
\left(\mathbf{k m}^{\mathbf{2}}\right)\end{array}$ & $\begin{array}{c}\text { Persentase } \\
(\mathbf{\%})\end{array}$ \\
\hline 1. & $0-2 \%$ & Datar sampai Landai & 210,36 & $30,27 \%$ \\
\hline 2. & $3-15 \%$ & Landai sampai Bergelombang & 50,98 & $7,34 \%$ \\
\hline 3. & $16-40 \%$ & Bergelombang sampai Berbukit & 124,74 & $17,95 \%$ \\
\hline 4. & $>40 \%$ & Berbukit sampai Bergunung & 305,88 & $44,45 \%$ \\
\hline \multicolumn{2}{|c|}{ Kota Padang } & & $\mathbf{6 9 1 , 9 6}$ & $\mathbf{1 0 0 , 0 0 \%}$ \\
\hline
\end{tabular}

Sumber Data Pokok Perencanaan Kota Padang Tahun 2012

Kawasan dengan kemiringan $0-2 \%$ umumnya terletak pada Kecamatan Padang Barat, Padang Timur, Padang Utara, Nanggalo, sebagian Kecamatan Kuranji, Kecamatan Padang Selatan, Kecamatan Lubuk Begalung dan Kecamatan Koto Tangah. Kawasan dengan kemiringan $2-15 \%$ tersebar di Kecamatan Koto Tangah, Kecamatan Pauh dan Kecamatan Lubuk Kilangan yakni berada pada bagian tengah Kota Padang dan kawasan dengan kemiringan $15 \%-40 \%$ tersebar di Kecamatan Lubuk Begalung, Lubuk Kilangan, Kuranji, Pauh dan Kecamatan Koto Tangah. Sedangkan kawasan dengan kemiringan lebih dari $40 \%$ tersebar di bagian timur Kecamatan Koto Tangah, Kuranji, Pauh, dan bagian selatan Kecamatan Lubuk Kilangan dan Lubuk Begalung dan 
sebagian besar Kecamatan Bungus Teluk Kabung. Kawasan dengan kemiringan $>40 \%$ ini merupakan kawasan yang telah ditetapkan sebagai kawasan hutan lindung Wilayah Kota Padang merupakan dataran yang landai dan semakin berbukit ke arah Timur dan kearah Selatan membentuk permukaan yang bergelombang dan melandai kearah Barat. Ketinggian wilayah daratan Kota Padang sangat bervariasi, yaitu antara 0-1.853 $\mathrm{m}$ di atas permukaan laut dengan daerah tertinggi adalah Kecamatan Lubuk Kilangan.

Berdasarkan data yang diperoleh dari survey dan data sekunder, maka hasilnya dapat di jelaskan sebagai berikut:

\section{A. Jalur Evakuasi}

Jalur evakuasi di kota padang yang diketahui dari studi ini jalan-jalan yang dapat digunakan sebagai jalur evakuasi. untuk lebih jelasnya jalan-jalan yang bisa dijadikan jalur evakuasi yang ada di kota padang dapat diperhatikan tabel berikut ini:

Tabel 3.3 Nama Ruas Jalan, Jenis Jalan Dan Lebar Jalan Di Kota Padang

\begin{tabular}{|l|l|l|c|}
\hline $\begin{array}{l}\text { N } \\
\text { o }\end{array}$ & Nama Ruas Jalan & Jenis & Lebar (m) \\
\hline 1 & Jl. Adinegoro & Arteri Sekunder & 16 \\
\hline 2 & Jl Anak Air & Kolektor Sekunder & 3 \\
\hline 3 & Jl By Pass & Arteri Primer & 9 \\
\hline 4 & Pasir Sebelah & Kolektor Sekunder & 6 \\
\hline 5 & Koto Pulai & Arteri Sekunder & 6 \\
\hline 6 & Raya Kalumpang & Arteri Sekunder & 6 \\
\hline 7 & Kampung Jambak & Kolektor Sekunder & 5 \\
\hline 8 & Tanggul Hitam & Kolektor Sekunder & 3 \\
\hline 9 & Rawang & Kolektor Sekunder & 3 \\
\hline 10 & Dadok Tunggul & Kolektor Sekunder & 3 \\
\hline 11 & Hitam & & \\
\hline 12 & Jl. Raden Saleh & Arteri Sekunder & 13.5 \\
\hline 13 & Jl. Khatib Sulaiman & Arteri Sekunder & 14.5 \\
\hline 14 & Jl. Jhonny Anwar & Arteri Sekunder & 14.5 \\
\hline 15 & Jl Gajah Mada & Arteri Sekunder & 12.5 \\
\hline 16 & Jl. Nipah & Arteri Sekunder & 7.5 \\
\hline 17 & Batang Arau & Arteri Sekunder & 7 \\
\hline 18 & Pulau Aia & Arteri Sekunder & 5.6 \\
\hline 19 & Ps Batipuh & Arteri Sekunder & 6 \\
\hline 20 & Parak Gadang & Kolektor Sekunder & 6 \\
\hline 21 & Gadang & & 6 \\
\hline 22 & Jl Sutan Syahrir & Arteri Sekunder & 6 \\
\hline
\end{tabular}




\begin{tabular}{|l|l|l|c|}
\hline $\begin{array}{l}\text { N } \\
\text { o }\end{array}$ & Nama Ruas Jalan & Jenis & Lebar (m) \\
\hline 23 & $\begin{array}{l}\text { Jl HOS } \\
\text { Cokroaminoto }\end{array}$ & Arteri Sekunder & 7 \\
\hline 24 & Tepi Pasang & Kolektor Sekunder & 5 \\
\hline 25 & Jl Imam Bonjol & Arteri Sekunder & 7.5 \\
\hline 26 & Jl M. Thamrin & Arteri Sekunder & 14.5 \\
\hline 27 & Ganting & Arteri Sekunder & 6 \\
\hline 28 & Parak Pisang & Arteri Sekunder & 5.6 \\
\hline 29 & Air Cama & Arteri Sekunder & 5.6 \\
\hline 30 & Jl Hang Tuah & Arteri Sekunder & 9 \\
\hline 31 & Jl. M. Yamin & Arteri Sekunder & 5 \\
\hline 32 & Jl. Proklamasi & Arteri Sekunder & 15 \\
\hline 33 & Jl. DR. Wahidin & Arteri Sekunder & 10.5 \\
\hline 34 & Jl. Sisingamangaraja & Arteri Sekunder & 9 \\
\hline 35 & Jl. Ololadang & Arteri Sekunder & 7.5 \\
\hline 36 & Jl. A. Yani & Arteri Sekunder & 14.5 \\
\hline 37 & Jl. Agus Salim & Arteri Sekunder & 14.5 \\
\hline 38 & Jl. Sawahan & Arteri Sekunder & 14.5 \\
\hline 39 & Jl. Andalas & Arteri Sekunder & 11.5 \\
\hline 40 & Jl. Purus V & Kolektor Sekunder & 5 \\
\hline 41 & Jl. Ujung Gurun & Kolektor Sekunder & 9.8 \\
\hline 42 & Jl. Mangunsarkoro & Kolektor Sekunder & 12 \\
\hline 43 & Jl. Perintis & Arteri Sekunder & 12.5 \\
\hline & Kemerdekaan & & \\
\hline
\end{tabular}

Berdasarkan tabel diatas dan hasil analisa SIG ditemukan 10 sektor jalur evakuasi yang berhubungan langsung dengan zona aman. Untuk lebih jelasnya dapat diperhatikan sebagai berikut:

1. Jl. Adinegoro-anak air- bypass

2. Jl. Adinegoro - Koto Pulai - By Pass

3. Kampung Jambak - By Pass

4. Jl. Raya Kalumpang - Kampung Jambak - By Pass

5. Simpang Tabing - By Pass

6. Tabing- lubuk minturun - by pass

7. Tunggul Hitam - Rawang - Dadok - Tunggul Hitam - By Pass

8. J1. Khatib Sulaiman - Jhony Anwar - Gajah Mada- by pass

9. J1. Raden Saleh - K.H.A Dahlan- by pass

10. Jalan ke pantai air manis

Dari data diatas dapat diketahui jalan yang sesuai untuk dijadikan jalur evakuasi adalah Jl. Adinegoro dengan lebar 16 m, Jl. K.H.A Dahlan, dan Jl. Khatib Sulaiman. Sedangkan jalan yang tidak cocok dijadikan jalur evakuasi adalah 
jalan di Tunggul Hitam - Rawang - Dadok - Tunggul Hitam - By Pass dengan lebar hanya $3 \mathrm{~m}$.

Setiap sektor jalur evakuasi yang ada di kota padang merupakan muara dari jalur-jalur evakuasi yang ada sekitarnya, mulai dari jalan-jalan di pesisir barat kota Padang. Semua jalan tersebut bermuara ke jalan by pass (zona aman), kecuali jalan yang menuju ke pantai air manis.

\section{B. Pergerakan penduduk dan jumlah pergerakan penduduk}

Kota Padang terdiri dari 11 kecamatan dengan 10 sektor jalur evakuasi yang tersebar. Berikut tabel pergerakan penduduk per sektor di tiap kecamatan:

Tabel 3.4 Pergerakan Penduduk/ Sektor Di Tiap Kecamatan di Kota

\section{Padang}

\begin{tabular}{|l|l|c|}
\hline \multicolumn{1}{|c|}{ Sektor } & \multicolumn{1}{|c|}{ Dari Kecamatan } & $\begin{array}{c}\text { Jumlah Pergerakan } \\
\text { Penduduk }\end{array}$ \\
\hline $\begin{array}{l}\text { Menuju } \\
\text { sektor 1 }\end{array}$ & Kec. Koto tangah & 3.216 \\
\hline $\begin{array}{l}\text { Menuju } \\
\text { sektor 2 }\end{array}$ & Kec. Koto tangah & 846 \\
\hline $\begin{array}{l}\text { Menuju } \\
\text { sektor 3 }\end{array}$ & Kec. Koto tangah & 1.391 \\
\hline $\begin{array}{l}\text { Menuju } \\
\text { sektor 4 }\end{array}$ & Kec. Koto tangah & 348 \\
\hline $\begin{array}{l}\text { Menuju } \\
\text { sektor 4 }\end{array}$ & Kec. Koto tangah & 1.972 \\
\hline $\begin{array}{l}\text { Menuju } \\
\text { sektor 5 }\end{array}$ & Kec. Koto tangah & 245 \\
\hline $\begin{array}{l}\text { Menuju } \\
\text { sektor 5 }\end{array}$ & Kec. Koto tangah & 924 \\
\hline $\begin{array}{l}\text { Menuju } \\
\text { sektor 6 }\end{array}$ & Kec. Koto tangah & 1.085 \\
\hline
\end{tabular}




\begin{tabular}{|c|c|c|}
\hline Sektor & Dari Kecamatan & $\begin{array}{c}\text { Jumlah Pergerakan } \\
\text { Penduduk }\end{array}$ \\
\hline $\begin{array}{l}\text { Menuju } \\
\text { sektor } 7\end{array}$ & Kec. Padang utara & 7.103 \\
\hline $\begin{array}{l}\text { Menuju } \\
\text { sektor } 7\end{array}$ & Kec. Padang utara & 2.996 \\
\hline $\begin{array}{l}\text { Menuju } \\
\text { sektor } 7\end{array}$ & Kec. Padang utara & 2.170 \\
\hline $\begin{array}{l}\text { Menuju } \\
\text { sektor } 7\end{array}$ & Kec. Koto tangah & 633 \\
\hline $\begin{array}{l}\text { Menuju } \\
\text { sektor } 8\end{array}$ & Kec. Padang utara & 8.083 \\
\hline $\begin{array}{l}\text { Menuju } \\
\text { sektor } 8\end{array}$ & Kec. Padang utara & 8.557 \\
\hline $\begin{array}{l}\text { Menuju } \\
\text { sektor } 9\end{array}$ & Kec. Padang barat & 13.132 \\
\hline $\begin{array}{l}\text { Menuju } \\
\text { sektor } 9\end{array}$ & Kec. Padang barat & 15.584 \\
\hline $\begin{array}{l}\text { Menuju } \\
\text { sektor } 9\end{array}$ & Kec. Padang barat & 10.576 \\
\hline $\begin{array}{l}\text { Menuku } \\
\text { zona aman }\end{array}$ & Kec. Kuranji & 773 \\
\hline $\begin{array}{l}\text { Menuku } \\
\text { zona aman }\end{array}$ & Kec. Lubuk begalung & 6.656 \\
\hline $\begin{array}{l}\text { Menuku } \\
\text { zona aman }\end{array}$ & Kec. Padang timur & 39.945 \\
\hline $\begin{array}{l}\text { Menuku } \\
\text { zona aman }\end{array}$ & Kec. Pauh & 69 \\
\hline $\begin{array}{l}\text { Menuku } \\
\text { zona aman }\end{array}$ & Kec. Padang selatan & 4.540 \\
\hline
\end{tabular}




\begin{tabular}{|c|c|c|}
\hline Sektor & Dari Kecamatan & $\begin{array}{c}\text { Jumlah Pergerakan } \\
\text { Penduduk }\end{array}$ \\
\hline $\begin{array}{l}\text { Menuku } \\
\text { zona aman }\end{array}$ & Kec. Padang selatan & 19.272 \\
\hline $\begin{array}{l}\text { Menuku } \\
\text { zona aman }\end{array}$ & Kec. Padang selatan & 19.157 \\
\hline $\begin{array}{l}\text { Menuku } \\
\text { zona aman }\end{array}$ & Kec. Lubuk begalung & 11.953 \\
\hline $\begin{array}{l}\text { Menuku } \\
\text { zona aman }\end{array}$ & Kec. Padang barat & 22.135 \\
\hline Sektor 1 & Kec. Koto tangah & 700 \\
\hline Sektor 10 & Kec. Lubuk begalung & 392 \\
\hline Sektor 10 & Kec. Padang selatan & 15.523 \\
\hline Sektor 2 & Kec. Koto tangah & 640 \\
\hline Sektor 3 & Kec. Koto tangah & 449 \\
\hline Sektor 4 & Kec. Koto tangah & 1.778 \\
\hline Sektor 5 & Kec. Koto tangah & 2.891 \\
\hline Sektor 6 & Kec. Koto tangah & 3.178 \\
\hline Sektor 7 & Kec. Koto tangah & 6.321 \\
\hline Sektor 7 & Kec. Kuranji & 2.003 \\
\hline Sektor 7 & Kec. Padang utara & 5.590 \\
\hline Sektor 7 & Kec. Nanggalo & 15.335 \\
\hline Sektor 8 & Kec. Nanggalo & 38.456 \\
\hline Sektor 8 & Kec. Kuranji & 9.499 \\
\hline Sektor 8 & Kec. Kuranji & 884 \\
\hline Sektor 8 & Kec. Padang utara & 11.088 \\
\hline Sektor 9 & Kec. Kuranji & 12.322 \\
\hline Sektor 9 & Kec. Nanggalo & 398 \\
\hline Sektor 9 & Kec. Padang utara & 14.115 \\
\hline Sektor 9 & Kec. Padang utara & 15.922 \\
\hline
\end{tabular}




\begin{tabular}{|l|l|r|}
\hline \multicolumn{1}{|c|}{ Sektor } & \multicolumn{1}{|c|}{ Dari Kecamatan } & $\begin{array}{c}\text { Jumlah Pergerakan } \\
\text { Penduduk }\end{array}$ \\
\hline Sektor 9 & Kec. Padang timur & 51.175 \\
\hline Zona aman & Kec. Bungus teluk kabung & 23.273 \\
\hline Zona aman & Kec. Koto tangah & 83.906 \\
\hline Zona aman & Kec. Kuranji & 77.601 \\
\hline Zona aman & Kec. Lubuk begalung & 40.665 \\
\hline Zona aman & Kec. Lubuk kilangan & 50.215 \\
\hline Zona aman & Kec. Pauh & 50.215 \\
\hline Zona aman & Kec. Pauh & 8325 \\
\hline
\end{tabular}

Sumber hasil analisa SIG, survey lapangan dan data sekunder 2014

Dari tabel diatas terlihat bahwa sektor yang bergerak ke zona aman adalah sektor 9 sebanyak 51.175 orang di kecamatan padang timur. Sektor yang mengalami yang mengalami pergerakan paling sedikit ke zona aman adalah penduduk yang menuju ke sektor 5 sebanyak 245 orang di Kecamatan Koto Tangah.

Untuk lebih jelasnya jumlah pergerakan penduduk di setiap sektor jalur evakuasi di Kota Padang dapat di perhatikan tabel berikut.

\section{Tabel arah pergerakan dan jumlah penduduk}

\begin{tabular}{|l|l|c|}
\hline No & Arah pergerakan & $\begin{array}{c}\text { Jumlah penduduk } \\
\text { (jiwa) }\end{array}$ \\
\hline 1 & Menuju Sektor 1 & 3.216 \\
\hline 2 & Menuju sektor 2 & 846 \\
\hline 3 & Menuju Sektor 3 & 1.391 \\
\hline 4 & Menuju Sektor 4 & 2.320 \\
\hline 5 & Menuju Sektor 5 & 1.169 \\
\hline 6 & Menuju Sektor 6 & 1.085 \\
\hline 7 & Menuju Sektor 7 & 12.902 \\
\hline 8 & Menuju Sektor 8 & 16.640 \\
\hline 9 & Menuju Sektor 9 & 39.292 \\
\hline
\end{tabular}




\begin{tabular}{|l|l|c|}
\hline No & Arah pergerakan & $\begin{array}{c}\text { Jumlah penduduk } \\
\text { (jiwa) }\end{array}$ \\
\hline 10 & Sektor 1 & 700 \\
\hline 12 & Sektor 10 & 15.915 \\
\hline 13 & sektor 2 & 640 \\
\hline 14 & Sektor 3 & 449 \\
\hline 15 & Sektor 4 & 1.778 \\
\hline 16 & Sektor 5 & 2.891 \\
\hline 17 & Sektor 6 & 3.178 \\
\hline 18 & Sektor 7 & 29.249 \\
\hline 19 & Sektor 8 & 59.927 \\
\hline 20 & Sektor 9 & 93.932 \\
\hline
\end{tabular}

Dari tabel diatas terlihat pergerakan terbesar terjadi pada sektor 9 dengan jumlah 93.932 orang, yang menuju sektor 9 sebanyak 39.292, berdasarkan hal tersebut total pergerakan yang menuju zona aman pada sektor 9 ini berjumlah 133.224 orang. Sedangkan yang paling rendah terjadi pada sektor 3 dengan jumlah 449 orang, yang menuju sektor 3 sebanyak 1.391 orang, dengan demikian total pergerakan yang menuju zona aman pada sektor 3 ini berjumlah 1.486 orang. Untuk lebih jelasnya bagaimana pergerakan penduduk pada masing-masing sektor dapat dilihat pada gambar dibawah ini. 


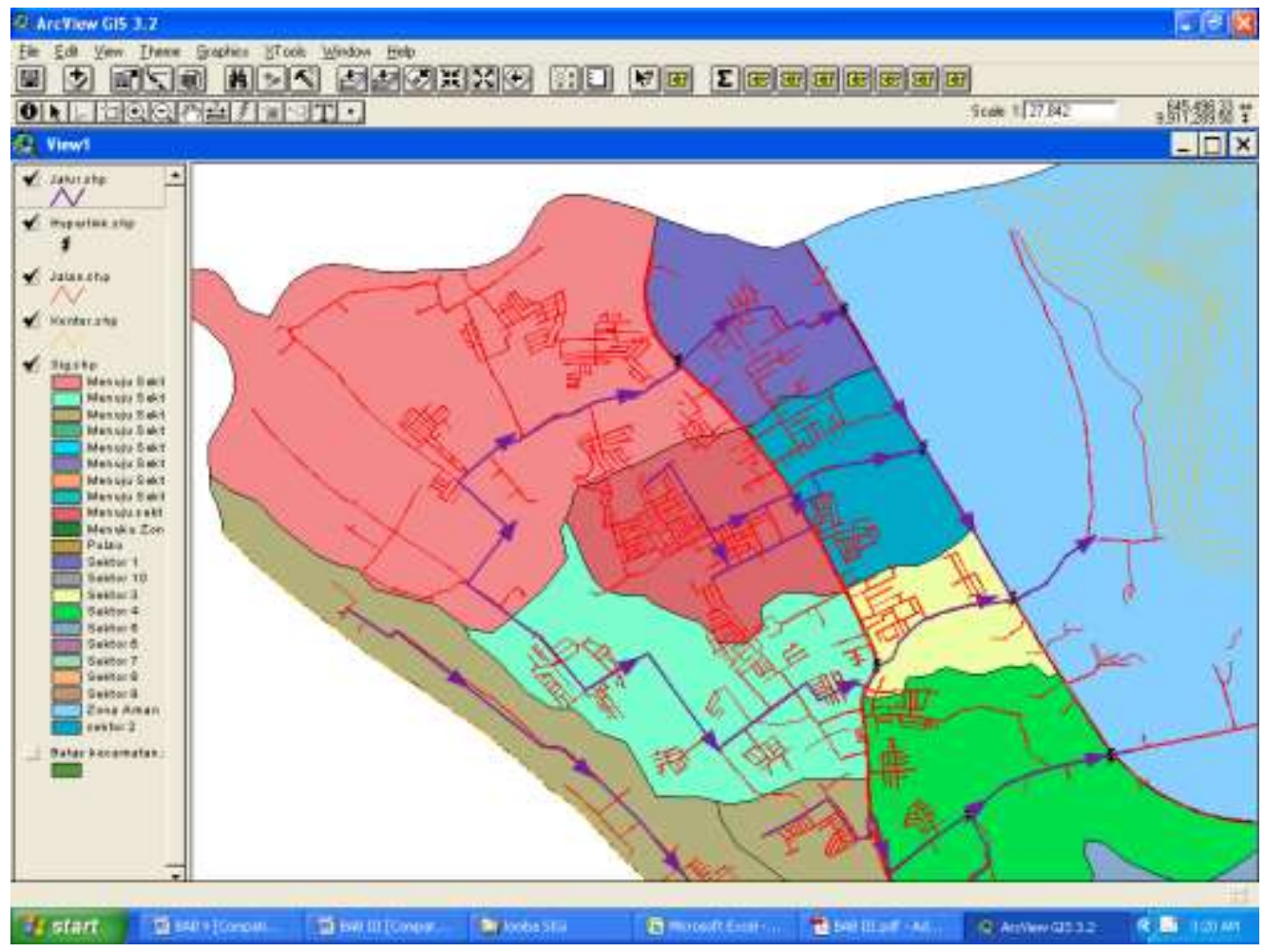

\section{KESIMPULAN}

Berdasarkan analisis SIG dan deskriptif berbasis keruangan yang dilakukan dalam penelitian ini, ditemukan temuan sebagai berikut:

1. Kota Padang mempunyai 10 sektor jalur evakuasi yang berhubungan langsung dengan zona aman. Jalan yang dijadikan jalur evakuasi dan memiliki lebar yang cukup adalah Jln. Adinegoro dengan lebar $16 \mathrm{~m}$. Jalan yang menjadi jalur evakuasi tetapi tidak memiliki lebar yang cukup adalah Jln. Tunggul Hitam dengan lebar hanya $3 \mathrm{~m}$.

2. Jumlah pergerakan penduduk paling banyak di zona rawan yang menuju zona aman ada pada sektor yang menuju sektor 7 sebanyak 51.175 jiwa di Kec. Padang Timur.

\section{DAFTAR PUSTAKA}

Arikunto, Suharsini. 2010. Prosedur Penelitian: Suatu Pendekatan Praktik. Rineka Cipta: Jakarta. 
Diposaptono, S., 2005. Teknologi Mitigasi Tsunami. Pelatihan Mitigasi, Kesiapsiagaan, dan Tanggap Darurat Bencana Tsunami di Wilayah Pesisir. Hlm 18

Prahasta, Eddy. 2001. Konsep-konsep Dasar Geographic Information System. Bandung: Informatika.

Prahasta, E. 2004. Sistem Informasi Geografis: ArcView lanjut.Informatika. Bandung

Prahasta, E. 2007. Sistem Infomasi Geografis: Tutorial Arc View. Informatika. Bandung

Sutikno. 1995. Geomorfologi Konsep dan Terapannya. Gadjah Mada: Yogyakarta. Taymaz, T. and Willige, B.T., 2006, Remote Sensing and GIS Contribution to Tsunami Risk Sites Detection of Coastal Areas in the Mediterranean. The Third International Conference on Early Warning, Bonn. 